\title{
Analisis Determinan Net Initial Return pada Perusahaan yang Melakukan IPO di Bursa Efek Indonesia
}

\author{
*Azizah Setya Ningrum ${ }^{1}$, Dewa Putra Khrisna Mahardika ${ }^{2}$ \\ 1,2Universitas Telkom
}

\section{ARTICLE INFO}

Article History:

Received: 04 June 2021

Accepted: 13 July 2021

Published: 13 July 2021

Keywords:

Current Ratio, Return On Asset, Offering, Underwriter Reputation, Net Initial Return

\begin{abstract}
This study aims to test and analyze Current Ratio, Return on Asset, Offering, and Underwriter Reputation against Net Initial Return in companies that conducted IPOs on the Indonesia Stock Exchange (IDX) for the period 2015-2019. The population of this study was 181 companies, with a sample of 108 companies for sampling using purposive sampling techniques. This study used IBM SPSS 25 as an analysis tool. The results showed that current ratio, return on asset, offering, and underwriter reputation simultaneously have a significant effect on Net Initial Return. Partially, current ratio and offering variables have no effect on Net Initial Return and Return On Asset and Underwriter Reputation have a significant negative effect on Net Initial Return.
\end{abstract}

ABSTRAK
Penelitian ini bertujuan untuk menganalisis dan menguji
variabel Current Ratio, Return On Asset, Offering, dan
Reputasi Underwriter terhadap tingkat Net Initial Return pada
perusahaan yang melakukan IPO di Bursa Efek Indonesia
(BEI) periode 2015-2019. Populasi penelitian ini adalah
sebanyak 181 perusahaan, dengan sampel sebanyak 108
perusahaan atas pengambilan sampel menggunakan teknik
purposive sampling. Penelitian ini menggunakan IBM SPSS
25 sebagai alat analisis. Hasil penelitian menunjukkan bahwa
Current Ratio, Return On Asset, Offering, dan Reputasi
Underwriter secara simultan berpengaruh signifikan terhadap
Net Initial Return. Secara parsial, variabel Current Ratio dan
Offering tidak berpengaruh terhadap Net Initial Return serta
pada variabel Return On Asset dan Reputasi Underwriter
memiliki pengaruh signifikan dengan arah negatif terhadap
Net Initial Return.

How to Cite:

Ningrum, Azizah Setya dan Dewa Putra Khrisna Mahardika. (2021). Analisis Determinan Net Initial Return pada Perusahaan yang Melakukan IPO di Bursa Efek Indonesia. Jurnal Ilmiah Wahana Akuntansi, 16(1), 94-110. https://doi.org/10.21009/ wahana.16.016 


\section{PENDAHULUAN}

Perusahaan membutuhkan suntikan modal yang besar dalam mengekspansi aktivitas bisnisnya agar perusahaan bisa bertahan untuk jangka waktu yang panjang. Selain itu, perusahaan selalu berusaha bergerak dalam skala yang besar di mana kebutuhan dana bagi perusahaan juga akan semakin meningkat. Pada sisi lain, pemegang saham memiliki dana yang terbatas sehingga menambah modal adalah suatu kebutuhan yang sangat diperlukan bagi perusahaan. Salah satu alternatif yang dapat dijalankan oleh perusahaan adalah dengan menerbitkan saham baru dan memperjualbelikan saham tersebut kepada masyarakat luas dengan pasar modal sebagai mediator (go public). Pasar modal merupakan suatu tempat terorganisasi yang dijadikan sebagai tempat perdagangan efekefek yang mempertemukan antar dua belah pihak antara pihak yang membutuhkan dana (emiten) dan pihak yang meminjamkan dana (investor) (Muklis, 2016). Untuk mendapatkan dana yang maksimal, perusahaan harus melakukan perdagangan saham pada pasar perdana. Perdagangan ini umumnya dikenal dengan penawaran umum saham perdana atau Initial Public Offering (IPO).

Gambar 1 di bawah ini merupakan data jumlah perusahaan yang melakukan IPO periode 2015-2019.

Berdasarkan gambar 1, sejak tahun 2015 sampai dengan tahun 2019 antusiasme perusahaan yang melakukan IPO di Bursa Efek Indonesia berfluktuatif. Tahun 2016 sampai dengan tahun 2018 perusahaan yang melakukan IPO mengalami peningkatan yang signifikan per tahunnya. Peningkatan tersebut disebabkan karena status perusahaan menjadi perusahaan publik. Dengan mengubah status tersebut, perusahaan akan sangat diuntungkan.

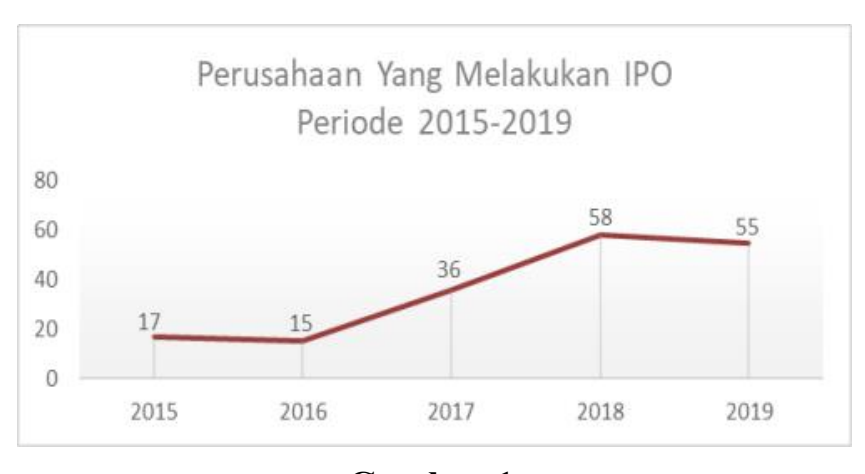

\section{Gambar 1}

Data Jumlah Perusahaan yang Melakukan IPO Periode 2015-2019

Sumber: http://www.e-bursa.com

\section{Menurut Undang-Undang No.8 Tahun} 1995, penawaran umum adalah kegiatan penawaran atas kepemilikan saham dan sejenisnya oleh suatu perusahaan untuk menjualnya kepada masyarakat dengan tata laksana yang sesuai dengan peraturan. Penilaian publik merupakan faktor yang sangat mempengaruhi besaran suntikan dana yang akan diberikan untuk berinvestasi di perusahaan tersebut. Sesuai dengan teori signalling di mana perusahaan terbuka akan informasi terkait perusahaan yang dapat dijadikan sinyal untuk para investor sebagai acuan membuat keputusan dalam berinvestasi (Purwanto, 2012).

Semua investor pada prinsipnya mempunyai tujuan yang sama saat menanamkan uangnya di pasar modal, yaitu investor yang paling utama dikelompokkan dalam dua hal yaitu keterbukaan emiten akan informasi dan tanggung jawab moral pengelolaan perusahaan publik tersebut. 
Keterbukaan informasi ini harus dimulai sejak perusahaan menyatakan dirinya go public, sejak menerbitkan prospektus dengan penawaran efek/ sahamnya (Umam \& Sutanto, 2017). Prospektus merupakan sumber informasi yang sangat penting dengan tujuan digunakan untuk senjata investor dalam memutuskan akan melakukan investasi atau tidak. Prospektus berisi informasi mengenai perusahaan, tujuan penggunaan dana, laporan keuangan terbaru dan historis, proyeksi laba, dan persentase dividen yang dijanjikan, analisis perbandingan dengan industri sejenis. Investor juga menganggap prospektus ini sebagai sumber referensi untuk mengurangi ketidakpastian (Sanjaya \& Lukman, 2020).

Permasalahan asimetri informasi kerap terjadi pada perusahaan yang hendak melakukan IPO dalam proses penawaran umum. Terjadinya perbedaan harga penutupan saham di pasar sekunder dengan harga saham pada IPO atau pada saat penawaran umum perdana merupakan dampak dari asimetri informasi. Dikatakan underpricing jika, harga saham pada saat penawaran perdana lebih rendah dibandingkan dengan harga saham penutupan hari pertama di pasar sekunder. Begitu pun dengan kondisi sebaliknya, jika harga saham saat penawaran perdana lebih tinggi dibanding harga saham di pasar sekunder, maka dapat disebut dengan istilah overpricing (Gunawan \& Jodin, 2017). Fenomena underpricing menghasilkan tingkat Net Initial Return yang tinggi, sehingga akan menguntungkan pada sisi investor karena investor akan menerima return tinggi dan termotivasi untuk membeli saham pada saat perusahaan melakukan penawaran perdana atau
IPO, sebaliknya pada sisi perusahaan kurang optimal dalam menghimpun dana karena sebagian keuntungan akan diperoleh investor.

Penelitian yang dilakukan oleh (Maulidya \& Lautania, 2016) dan (Linazah et al., 2015) menyatakan bahwa Current Ratio (CR) berpengaruh signifikan dengan arah negatif terhadap Net Initial Return. Berbeda dengan penelitian yang dilakukan oleh (Wildahayu \& Priantinah, 2019) dan (Radipria et al., 2015) yang menyatakan bahwa Current Ratio tidak berpengaruh terhadap Net Initial Return. Penelitian yang dilakukan oleh (Wildahayu \& Priantinah, 2019) dan (Hidayati \& Triyanto, 2020) menyatakan bahwa ROA berpengaruh signifikan dengan arah negatif terhadap Net Initial Return. Berbeda dengan penelitian yang dilakukan oleh (Albada et al., 2018) dan (Setiawan, 2018) yang menyatakan bahwa ROA tidak memiliki pengaruh signifikan terhadap Net Initial Return. Penelitian yang dilakukan oleh (Khin et al., 2016) yang menyatakan bahwa Offering berpengaruh signifikan dengan arah positif terhadap Net Initial Return. Sedangkan, penelitian yang dilakukan oleh (Kartika \& Putra, 2017) menyatakan bahwa Offering tidak berpengaruh terhadap Net Initial Return. Penelitian yang dilakukan oleh (Hidayati \& Triyanto, 2020) dan (Kuncoro \& Suryaputri, 2019) yang menyatakan bahwa Reputasi Underwriter berpengaruh signifikan dengan arah negatif terhadap Net Initial Return. Berbeda dengan penelitian yang dilakukan oleh (Hadi, 2019) dan (Badru \& Ahmad-Zaluki, 2018) yang menyatakan bahwa Reputasi Underwriter tidak berpengaruh terhadap Net 
Initial Return.

Ketidakkonsistenan hasil penelitian terdahulu membuat Peneliti terdorong untuk melakukan penelitian dengan topik yang sama yaitu mengenai faktor-faktor yang dianggap dapat mempengaruhi tingkat Net Initial Return dengan menggunakan variabel Current Ratio dan Return On Asset sebagai faktor akuntansi serta Offering dan Reputasi Underwriter sebagai faktor non-akuntansi. Berdasarkan penjelasan diatas, Peneliti tertarik melakukan penelitian kembali yang berjudul: "Analisis Determinan Net Initial Return". Tujuan penelitian yakni menganalisis dan menguji variabel Current Ratio, Return On Asset, Offering, dan Reputasi Underwriter terhadap tingkat Net Initial Return pada perusahaan yang melakukan IPO di Bursa Efek Indonesia (BEI) periode 2015-2019.

\section{TINJAUAN PUSTAKA}

\section{Teori Signalling}

Perusahaan yang melakukan Initial Public Offering (IPO) yang mengalami underpricing sangat erat kaitannya dengan Teori Signalling. Underpricing adalah harga saham pada saat penawaran perdana lebih rendah dibandingkan dengan harga saham penutupan hari pertama di pasar sekunder. Teori Signalling menjelaskan tentang dorongan bagi perusahaan agar memberikan informasi laporan keuangan kepada pihak eksternal dengan tujuan meningkatkan value perusahaan dan menunjukkan bahwa perusahaan memiliki keunggulan/nilai lebih dibandingkan dengan perusahaan lain agar investor tertarik untuk melakukan investasi di perusahaan tersebut.
Menurut (Aryapranata \& Adityamarwan, 2017) teori signalling juga sebagai tanda bagi calon investor untuk pengambilan keputusan investasi karena emiten dengan sengaja mempublikasikan informasi private. Jika informasi yang diterima oleh calon investor berupa sinyal positif atau bisa dikatakan good news, maka ketidakpastian yang diinterpretasikan calon investor atas nilai pasar perusahaan akan berkurang. Menurut (Yuniarti \& Syarifudin, 2020) teori signalling mengasumsikan bahwa penerbit laporan keuangan sebagai pemilik informasi yang relevan serta sempurna tentang perusahaan, sedangkan investor sebagai pihak penerima informasi atau entitas uninformed yang sangat awam akan informasi perusahaan, yang kemudian pihak penerima akan menentukan keputusannya untuk berinvestasi atas sinyal tersebut. Sesuai dengan teori signalling di mana perusahaan terbuka akan informasi terkait perusahaan yang dapat dijadikan sinyal untuk para investor sebagai acuan membuat keputusan dalam berinvestasi (Purwanto, 2012).

\section{Asimetri Informasi}

Asimetri informasi adalah sebuah ketidakseimbangan atau perbedaan akan sebuah informasi tertentu, di mana salah satu pihak memiliki informasi lebih banyak sehingga bisa lebih mengetahui (pihak pengelola) dibandingkan pihak lainnya (Hadi, 2019). Menurut (Scott, 2015) asimetri informasi merupakan kondisi dalam aktivitas jual beli di mana terdapat salah satu pihak dalam transaksi tersebut memiliki keunggulan dan kelebihan 
mengenai aset yang diperdagangkan dibandingkan dengan pihak yang lainnya. Beberapa literatur menjelaskan asimetri informasi atas perbedaan informasi yang dimiliki oleh para pihak-pihak yang terlibat dalam penawaran saham perdana mengakibatkan terjadinya fenomena underpricing. Penjamin emisi efek (underwriter) memiliki informasi yang lebih menyeluruh dibandingkan emiten terhadap calon investor. Informasi yang dimiliki oleh penjamin emisi efek dimanfaatkannya untuk membuat persetujuan dengan emiten atas harga IPO yang optimal baginya, yaitu dengan memperkecil informasi yang ada, sehingga emiten dapat menentukan harga yang murah bagi penawaran sahamnya.

\section{Initial Public Offering (IPO)}

Initial Public Offering atau dikenal juga dengan istilah penawaran saham perdana merupakan kegiatan jual beli berbagai instrumen pasar modal untuk pertama kalinya yang dilakukan oleh emiten kepada masyarakat luas dan harus sesuai dengan peraturan yang berlaku yakni Undang-Undang Pasar Modal Pasal 1 Butir 15 yang berbunyi "Kegiatan penawaran efek yang dilakukan oleh emiten untuk menjual efek kepada masyarakat berdasarkan tata cara yang diatur dalam undang-undang ini dan peraturan pelaksanaannya”.

Penawaran umum dapat dijadikan salah satu alternatif sebagai sumber pendanaan untuk perusahaan yang akan go public dalam rangka mengekspansi usaha dan sekaligus dapat meningkatkan ekuitas perusahaan. Biasanya, perusahaan publik akan terus terpublikasi dan mendapatkan porsi pemberitaan di media masa akan adanya quotation secara rutin atas harga saham.

\section{Net Initial Return (NIR)}

Net Initial Return adalah keuntungan yang didapatkan pemegang saham karena adanya perbedaan harga saham yang dibeli pada pasar perdana (saat IPO) dengan harga jual saham dihari pertama pada pasar sekunder (Sari, 2020). Net Initial Return dengan rata-rata positif merupakan keuntungan bagi investor atas harga saham perdana yang mengalami underpriced yang saham tersebut telah diperdagangkan di bursa sebelumnya (Hadi, 2019). Pihak investor cendrung mengharapkan tingginya tingkat underpricing karena investor akan mendapatkan keuntungan Net Initial Return yang lebih tinggi. Persentase Net Initial Return didapatkan dengan membandingkan selisih harga saham di pasar sekunder dengan harga saham pada penawaran perdana.

\section{Current Ratio (CR)}

Current Ratio (CR) merupakan salah satu bagian dari rasio likuiditas yang kerap kali digunakan untuk mengetahui tingkat kemampuan perusahaan dalam melunasi kewajiban jangka pendeknya dengan asset lancar (Anah et al., 2018). Suatu perusahaan yang memiliki nilai Current Ratio menunjukkan nilai $200 \%$ atau $2: 1$, dianggap sebagai besaran nilai yang baik atau memuaskan bagi tingkat likuiditas perusahaan tersebut dan dapat dikatakan berada dalam posisi aman untuk jangka pendek. Perusahaan 
yang memiliki nilai Current Ratio dibawah 1, diindikasikan perusahaan sedang mengalami krisis keuangan dan akan berdampak mengurangi kepercayaan investor (Tambunan, 2015). Tingginya rasio Current Ratio (CR) menunjukkan perusahaan semakin mampu memenuhi kewajiban jangka pendeknya, yang akan membuat investor lebih tertarik karena perusahaan dengan Current Ratio (CR) yang tinggi dapat meminimalisir risiko dalam berinvestasi dan terhindar dari underpricing atau semakin rendah Net Initial Return.

Penelitian yang dilakukan oleh (Maulidya \& Lautania, 2016) dan (Linazah et al., 2015) menyatakan bahwa Current Ratio (CR) berpengaruh signifikan dengan arah negatif terhadap Net Initial Return. Berbeda dengan penelitian yang dilakukan oleh (Wildahayu \& Priantinah, 2019) dan (Radipria et al., 2015) yang menyatakan bahwa Current Ratio tidak berpengaruh terhadap Net Initial Return.

$\mathrm{H}_{1}$ : Current Ratio (CR) berpengaruh dengan arah negatif terhadap Net Initial Return

\section{Return On Asset (ROA)}

Return On Asset (ROA) termasuk ke dalam bagian rasio profitabilitas di mana ROA dijadikan sebagai standar dalam mengukur tingkat efektivitas dan efisiensi manajemen dalam mengelola perusahaan untuk memperoleh keuntungan yang maksimal dengan cara memanfaatkan aktiva yang dimilikinya (Novitasari \& Cahyati, 2018). Perusahaan dengan ROA yang tinggi dapat mengurangi ketidakpastian dalam menentukan harga saham yang wajar pada IPO atau saat penawaran saham perdana yang akan menurunkan tingkat underpricing (Gunawan \& Jodin, 2017). Semakin tinggi ROA yang dihasilkan oleh perusahaan menunjukkan perusahaan mampu mengasilkan keuntungan atau laba yang tinggi pula, sehingga investor dapat melihat bahwa perusahaan tersebut akan menguntungkan dan akan mengurangi ketidakpastian dalam menentukan harga saham yang wajar pada Initial Public Offering atau saat penawaran saham perdana yang akan menurunkan tingkat underpricing (Gunawan \& Jodin, 2017).

Penelitian yang dilakukan oleh (Wildahayu \& Priantinah, 2019) dan (Hidayati \& Triyanto, 2020) menyatakan bahwa ROA berpengaruh signifikan dengan arah negatif terhadap Net Initial Return. Berbeda dengan penelitian yang dilakukan oleh (Albada et al., 2018) dan (Setiawan, 2018) yang menyatakan bahwa ROA tidak memiliki pengaruh signifikan terhadap Net Initial Return.

$\mathrm{H}_{2}$ : Return On Asset (ROA) berpengaruh dengan arah negatif terhadap Net Initial Return

\section{Offering}

Offering atau persentase penawaran saham ke publik adalah suatu perbandingan antara jumlah saham yang dijual kepada masyarakat atau publik saat IPO dengan total saham yang beredar (Syukur et al., 2018). Dapat dikatakan Offering adalah porsi kepemilikan saham yang akan dikuasai publik nantinya. Persentase saham yang ditawarkan menjadi proksi terhadap faktor ketidakpastian yang akan menjadi pertimbangan oleh investor. 
Persentase dari saham yang ditawarkan kepada pemegang saham baru menggambarkan aliran informasi dari saham emiten kepada calon investor. Semakin kecil persentase saham yang ditawarkan akan meminimalisir ketidakpastian bagi investor di masa yang akan datang. Begitu pun sebaliknya, pula sebaliknya, semakin besar proporsi saham yang ditawarkan kepada pemegang saham baru, semakin tinggi tingkat ketidakpastiannya, sehingga harga yang ditetapkan saat IPO menjadi rendah. Harga penawaran yang rendah menjadi peluang yang besar terjadinya underpricing.

Penelitian yang dilakukan oleh (Khin et al., 2016) yang menyatakan bahwa Offering berpengaruh signifikan dengan arah positif terhadap Net Initial Return. Sedangkan, penelitian yang dilakukan oleh (Kartika \& Putra, 2017) menyatakan bahwa Offering tidak berpengaruh terhadap Net Initial Return.

$\mathrm{H}_{3}$ : Offering berpengaruh dengan arah positif terhadap Net Initial Return

\section{Reputasi Underwriter}

Penjamin Emisi Efek atau biasa disebut dengan underwriter merupakan perusahaan sekuritas yang membuat kontrak dengan emiten yang akan melakukan penawaran umum dengan menerbitkan sahamnya di pasar modal (Fahmi, 2017). Perusahaan efek inilah yang bertanggungjawab atas terjual atau tidaknya efek yang ditawarkan oleh perusahaan. Penjamin emisi efek akan melakukan mengupayakan kinerjanya untuk menghindari ketidakpastian tersebut dengan tujuan menjaga reputasi serta kualitas yang telah dimilikinya. Semakin tinggi kualitas dan reputasi baik yang dimiliki sebuah penjamin emisi efek diindikasi dapat mengurangi tingkat ketidakpastian yang akan mengakibatkan penurunan terhadap Net Initial Return bagi investor.

Penelitian yang dilakukan oleh (Hidayati \& Triyanto, 2020) dan (Kuncoro \& Suryaputri, 2019) yang menyatakan bahwa Reputasi Underwriter berpengaruh signifikan dengan arah negatif terhadap Net Initial Return. Berbeda dengan penelitian yang dilakukan oleh (Hadi, 2019) dan (Badru \& Ahmad-Zaluki, 2018) yang menyatakan bahwa Reputasi Underwriter tidak berpengaruh terhadap Net Initial Return.

\section{$\mathrm{H}_{4}$ : Reputasi Underwriter berpengaruh dengan arah negatif terhadap Net Initial Return}

Berdasarkan teori yang telah dijelaskan di atas, maka kerangka penelitian dari penelitian ini disajikan pada Gambar 2 di bawah ini.

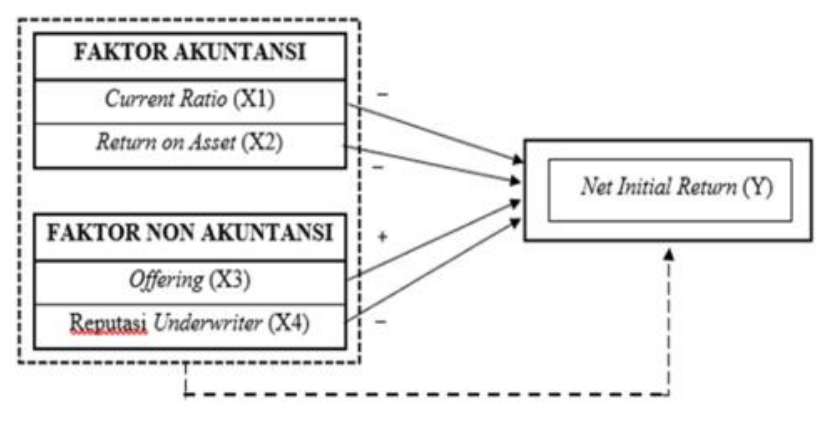

Gambar 2

Kerangka Penelitian

Sumber: Data diolah oleh peneliti, Tahun 2021

\section{METODE PENELITIAN}

Penelitian ini termasuk ke dalam kategori penelitian kuantitatif dengan menggunakan data 
sekunder yang bersumber dari prospektus maupun laporan keuangan perusahaan yang melakukan IPO yang diperoleh dari website resmi Bursa Efek Indonesia maupun website resmi perusahaan terkait. Periode yang digunakan dalam penelitian ini yaitu dari tahun 2017 sampai dengan 2019.

Populasi dalam penelitian ini adalah perusahaan yang melakukan IPO di Bursa Efek Indonesia periode 2017-2019 sebanyak 181 perusahaan. Sampel akhir dari penelitian yakni terpilih sebanyak 108 perusahaan dengan menggunakan metode non-probability sampling yaitu purposive sampling.

Kriteria sampel penelitian ini disajikan pada Tabel 1 .

\section{Tabel 1}

\section{Kriteria Pemilihan Sampel}

\begin{tabular}{|c|c|c|}
\hline No & $\begin{array}{l}\text { Kriteria Sampel } \\
\end{array}$ & Jumlah \\
\hline 1 & $\begin{array}{l}\text { Perusahaan yang melakukan IPO di BEI } \\
\text { periode } 2015-2019 \text {. }\end{array}$ & 181 \\
\hline 2 & $\begin{array}{l}\text { Perusahaan yang melakukan IPO yang } \\
\text { tidak memiliki data prospektus lengkap } \\
\text { periode } 2015-2019 \text {. }\end{array}$ & $(58)$ \\
\hline 3 & $\begin{array}{l}\text { Perusahaan yang mengalami overpricing } \\
\text { pada penawaran perdana (IPO) selama } \\
\text { periode } 2015-2019 \text {. }\end{array}$ & (15) \\
\hline & Total Sampel & 10 \\
\hline
\end{tabular}

Sumber: Data diolah oleh peneliti, Tahun 2021

Operasionalisasi variabel dari penelitian ini disajikan pada Tabel 2.

\section{TEKNIK ANALISIS DATA}

\section{Statistik Deskriptif}

Statistik deskriptif digunakan untuk menganalisis data dengan menggambarkan karakteristik data yang telah terkumpul yang memiliki tujuan untuk mempermudah pembaca dalam memahami data tanpa bermaksud untuk membuat kesimpulan atau generalisasi (Sujarweni, 2015:113). Statistik deskriptif ini digunakan untuk mendeskripsikan Current Ratio (CR), Return On Asset (ROA), Offering, Reputasi Underwriter dengan alat ukur rata-rata, nilai maksimum, nilai minimum, dan standar deviasi.

Tabel 2

Operasionalisasi Variabel

\begin{tabular}{|c|c|c|}
\hline Variabel & Indikator & Skala \\
\hline $\begin{array}{l}\text { Current } \\
\text { Ratio (CR) }\end{array}$ & Current Asset $\times 100 \%$ & Rasio \\
\hline $\begin{array}{l}\text { Return On } \\
\text { Assets (ROA) }\end{array}$ & $\begin{array}{l}\text { Current Liabilities } \\
\frac{\text { EBIT }}{\text { Total Asset }} \times 100 \%\end{array}$ & Rasio \\
\hline Offering & $\frac{\text { Number of Share Offered to the Public }}{\text { Number os Shares Outstanding }} \times 100 \%$ & Rasio \\
\hline $\begin{array}{l}\text { Reputasi } \\
\text { Underwriter }\end{array}$ & 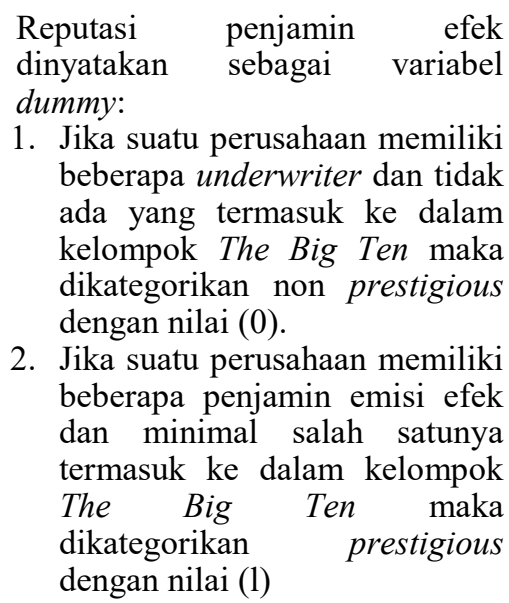 & Nominal \\
\hline $\begin{array}{l}\text { Net Initial } \\
\text { Return }\end{array}$ & $\frac{\text { Closing Price }-O \text { ffering Price }}{\text { Offering Price }} \times 100 \%$ & Rasio \\
\hline
\end{tabular}

Sumber: Data diolah oleh peneliti, Tahun 2021

\section{Uji Normalitas}

Uji asumsi klasik ini dilakukan untuk menguji apakah model regresi linear variabel dependen dengan variabel independen apakah keduanya memiliki distribusi normal atau tidak. Model regresi yang baik yaitu memiliki data yang dapat terdistribusi dengan normal atau mendekati normal (Ghozali, 2018:161). Dalam mendeteksi normalitas salah satu pengujian 
yang dapat digunakan yaitu Uji Kolmogorov Smirnov. Pedoman keputusan yang digunakan dalam Uji Kolmogorov-Smirnov yakni: 1) Asymp. Sig $>0.05$, maka $\mathrm{H}_{0}$ diterima data residual terdistribusi normal; 2) Asymp. Sig < 0.05, maka $\mathrm{H}_{0}$ ditolak data residual tidak terdistribusi normal; 3) Asymp. Sig $=0.05$, maka $\mathrm{H}_{0}$ diterima data residual terdistribusi normal.

\section{Uji Multikolinearitas}

Uji multikolinearitas dilakukan untuk menguji apakah model regresi memiliki korelasi antar variabel bebas. Multikolinearitas merupakan situasi di mana terdapat keterkaitan variabelvariabel independen yang satu dengan yang lainnya. Pengujian ini dilakukan dengan menggunakan korelasi antar variabel-variabel bebas yang akan digunakan dalam persamaan regresi dengan menghitung nilai tolerance dan VIF (Variance Information Factors) (Rochaety et al., 2019). Untuk melihat terdapat gejala multikolinearitas yaitu dengan: 1) Jika nilai tolerance $<0.10$ atau VIF $>10$ : terjadi multikolinearitas; 2) Jika nilai tolerance $=0.10$ atau VIF = 10: terjadi multikolinearitas; 3) Jika nilai tolerance $>0.10$ atau VIF $<10$ : tidak terjadi multikolinearitas.

\section{Uji Heteroskedastisitas}

Uji heteroskedastisitas dilakukan untuk memastikan apakah model regresi terjadi ketidaksamaan variance dari residual suatu pengamatan ke pengamatan yang lain. Heteroskedastisitas adalah varian variabel terikat dalam model tidak equal terhadap variabel bebas. Konsekuensi terjadinya heteroskedastisitas dalam model regresi adalah estimator yang diperoleh tidak efisien, baik berupa sampel kecil atau besar.

\section{Uji Autokorelasi}

Uji autokorelasi bertujuan untuk menguji apakah dalam suatu model regresi linear terdapat korelasi antara kesalahan pada periode t-1 (sebelumnya). Jika terjadi korelasi dapat dikatakan ada problem autokorelasi (Ghozali, 2018:95). Untuk mendeteksi ada atau tidaknya gejala autokorelasi maka dapat diuji dengan uji Durbin Watson (DW Test). Bentuk data dalam penelitian ini cross section, dapat diputuskan bahwa penelitian ini tidak melakukan uji autokorelasi karena data cross section tidak terikat dengan dimensi waktu (Gani \& Amalia, 2018).

\section{Analisis Regresi Linier Berganda}

Regresi ini digunakan menjelaskan hubungan fungsional antara beberapa variabel, yang terdiri dari variabel dependen dan lebih dari satu variabel independen. Regresi linier berganda adalah hasil dari penelitian yang memiliki variabel independen lebih dari satu. Analisis regresi yang digunakan pada penelitian ini adalah analisis regresi linear berganda.

Persamaan analisis regresi linier berganda pada penelitian ini adalah sebagai berikut:

$$
\begin{aligned}
\mathrm{NIR}= & \alpha+\beta 1 \mathrm{CR}+\beta 2 \mathrm{ROA}+\beta 3 \text { OFFERING } \\
& +\beta 4 \text { UNDERWRITER }+\varepsilon
\end{aligned}
$$

Keterangan:

$\begin{array}{ll}\text { NIR } & : \text { Net Initial Return } \\ \text { CR } & : \text { Current Ratio } \\ \text { ROA } & : \text { Return On Assets }\end{array}$




$\begin{array}{ll}\text { OFFERING } & : \text { Persentase Penawa } \\ \text { UNDERWRITER } & \text { Saham } \\ \alpha & : \text { Reputasi Underwriter } \\ \beta & : \text { Konstanta } \\ \varepsilon & : \text { Error }\end{array}$

\section{Koefisien Determinasi $\left(\mathbf{R}^{\mathbf{2}}\right)$}

Analisis Koefisien Determinasi $\left(R^{2}\right)$ sebuah analisis yang menyebutkan proporsi (persentase) variasi perubahan nilai-nilai variabel dependen yang ditentukan oleh perubahan nilai-nilai variabel independen (Gani \& Amalia, 2018). Nilai $\mathrm{R}^{2}$ yang bernilai kecil menggambarkan bahwa terbatasnya kemampuan variabel independen dalam menjelaskan variabel dependen. Jika $\mathrm{R}^{2}$ sama dengan atau lebih dari satu menandakan variabel independen memberikan semua informasi yang dibutuhkan untuk memprediksi variabel dependen.

\section{Pengujian Simultan (Uji F)}

Menurut (Ghozali, 2018:178), pengujian simultan digunakan untuk menguji apakah variabel dapat bersama-sama berpengaruh signifikan terhadap variabel dependen. Uji F digunakan untuk menguji pengaruh antara Current Ratio (CR), Return On Asset (ROA), Offering, dan Reputasi Underwriter terhadap Net Initial Return pada perusahaan yang melakukan IPO di Bursa Efek Indonesia secara simultan.

\section{Pengujian Parsial (Uji t)}

Menurut (Sugiyono, 2017:146), uji t digunakan untuk mengetahui seberapa jauh variabelvariabel independen secara individual berpengaruh dominan terhadap variabel dependen dengan nilai signifikansi 5\%, dengan apabila nilai probabilitas $<(\alpha=5 \%)$ maka $\mathrm{H}_{0}$ ditolak atau jika nilai probabilitas $>(\alpha=5 \%)$ maka $\mathrm{H}_{0}$ diterima.

\section{HASIL DAN PEMBAHASAN}

\section{Statistik Deskriptif}

Pengujian dalam penelitian ini menggunakan aplikasi IBM SPSS Statistics 25. Data yang digunakan pada analisis statistik deskriptif ini sebanyak 108 perusahaan, terdapat data outlier sebanyak 37 perusahaan, sehingga analisis data deskriptif menggunakan sampel data terakhir sebanyak 71 perusahaan.

Hasil statistik deskriptif dari penelitian ini disajikan pada Tabel 3.

Tabel 3

\section{Statistik Deskriptif}

\begin{tabular}{lrrrrc}
\hline & N & $\begin{array}{c}\text { Mini- } \\
\text { mum }\end{array}$ & $\begin{array}{c}\text { Maxi- } \\
\text { mum }\end{array}$ & Mean & $\begin{array}{c}\text { Std. } \\
\text { Devia- } \\
\text { tion }\end{array}$ \\
\hline CR & 71 & 0,077500 & 2,766141 & 1,222013 & 0,632796 \\
ROA & 71 & $-0,034619$ & 0,208044 & 0,057377 & 0,057000 \\
OFFERING & 71 & 0,049985 & 0.431818 & 0,251501 & 0,085811 \\
UNDERWRITER & 71 & 0,000000 & 1,000000 & 0,366197 & 0,485193 \\
NIR & 71 & 0,004545 & 0,700000 & 0,449878 & 0,247530 \\
\hline
\end{tabular}

Sumber: Data diolah oleh peneliti, Tahun 2021

Berdasarkan Tabel 3 di atas besar dari nilai minimum, maksimum, rata-rata (mean) dan standar deviasi dari total sampel berjumlah 71 perusahaan yang melakukan IPO di Bursa Efek Indonesia periode 2015-2019. Nilai mean dari Current Ratio yaitu sebesar 1.222013. Perusahaan dengan Current Ratio di atas ratarata sebanyak 34 perusahaan dan perusahaan dengan Current Ratio di bawah rata-rata sebanyak 37 perusahaan. Hal tersebut menunjukkan bahwa perusahaan dengan nilai 
mendominasi.

Nilai mean dari Return On Asset yaitu sebesar 0.057377. Perusahaan dengan Return On Asset di atas rata-rata sebanyak 29 perusahaan dan perusahaan dengan Return On Asset di bawah rata-rata sebanyak 42 perusahaan. Hal tersebut menunjukkan bahwa perusahaan dengan nilai Return On Asset di bawah rata-rata telah mendominasi.

Nilai mean dari Offering yaitu sebesar 0.251501. Perusahaan dengan Offering di atas rata-rata sebanyak 32 perusahaan dan perusahaan dengan Offering di bawah rata-rata sebanyak 39 perusahaan. Hal tersebut menunjukkan bahwa perusahaan dengan nilai Offering di bawah ratarata telah mendominasi.

Nilai dari perusahaan yang memiliki Underwriter atau Penjamin Emisi Efek dalam kategori The Big Ten yaitu sejumlah 30 perusahaan dan perusahaan yang memiliki Underwriter atau Penjamin Emisi Efek tidak termasuk ke dalam kategori The Big Ten yaitu sejumlah 41 perusahaan. Hal tersebut menunjukkan bahwa perusahaan yang memiliki Underwriter atau Penjamin Emisi Efek tidak termasuk ke dalam kategori The Big Ten telah mendominasi.

Nilai mean dari Net Initial Return yaitu sebesar 0.449878. Perusahaan dengan Net Initial Return di atas rata-rata sebanyak 50 perusahaan dan perusahaan dengan Net Initial Return di bawah rata-rata sebanyak 21 perusahaan. Hal tersebut menunjukkan bahwa perusahaan dengan nilai Net Initial Return di atas rata-rata telah mendominasi dan mengalami underpricing.

\section{Hasil Uji Normalitas}

Penelitian ini menggunakan uji Kolmogorov-Smirnov untuk menguji normalitas data. Hasil uji Kolmogorov-Smirnov dari penelitian ini disajikan pada Tabel 4 .

\section{Tabel 4}

Hasil Uji Kolmogorov-Smirnov

\begin{tabular}{llr}
\hline & & $\begin{array}{c}\text { Unstandardized } \\
\text { Residual }\end{array}$ \\
\hline $\mathrm{N}$ & & 71 \\
Normal Parameters $^{\mathrm{a}, \mathrm{b}}$ & Mean & .0000000 \\
& Std. & .21311697 \\
Most Extreme & Deviation & .143 \\
Differences & Absolute & .095 \\
& Positive & -.143 \\
Test Statistic & Negative & .143 \\
Asymp. Sig. (2-tailed) & & $.093^{\mathrm{c}}$ \\
\hline
\end{tabular}

Sumber: Data diolah oleh peneliti, Tahun 2021

Berdasarkan Tabel 4 di atas, hasil pengujian normalitas dengan menggunakan uji Kolmogorov-Smirnov, nilai Asymp. Sign. (2tailed) adalah sebesar 0.093 yang berarti bahwa nilai Asymp. Sign. (2-tailed) >0.05, maka dapat disimpulkan data terdistribusi secara normal.

\section{Hasil Uji Multikolinearitas}

Hasil uji multikolinearitas dari penelitian ini disajikan pada Tabel 5.

Tabel 5

Hasil Uji Multikolinearitas

\begin{tabular}{|c|c|c|}
\hline \multirow[b]{2}{*}{ Model } & \multicolumn{2}{|c|}{ Collinearity Statistics } \\
\hline & Tolerance & VIF \\
\hline (Constant) & & \\
\hline $\mathrm{CR}$ & 0,963 & 1,008 \\
\hline ROA & 0,993 & 1,038 \\
\hline OFFERING & 0,965 & 1,014 \\
\hline UNDERWRITER & 0,983 & 1,211 \\
\hline
\end{tabular}

Sumber: Data diolah oleh peneliti, Tahun 2021

Berdasarkan Tabel 5 di atas menunjukkan hasil uji multikolinearitas masing-masing 
variabel independen dengan nilai tolerance > 0,10 atau $\mathrm{VIF}<10$, hal tersebut membuktikan bahwa data penelitian terbebas dari gejala multikolinearitas.

\section{Hasil Uji Heteroskedastisitas}

Hasil uji heteroskedastisitas dari penelitian ini disajikan pada Tabel 6 .

Tabel 6

Hasil Uji Heteroskedastisitas

\begin{tabular}{llr}
\hline \multicolumn{2}{c}{ Model } & Sig. \\
\hline 1 & (Constant) & 0,000 \\
& CR & 0,097 \\
& ROA & 0,055 \\
& OFFERING & 0,078 \\
& UNDERWRITER & 0,144 \\
& NIR & 0,086 \\
\hline
\end{tabular}

Sumber: Data diolah oleh peneliti, Tahun 2021

Berdasarkan Tabel 6 di atas dapat dilihat bahwa nilai signifikansi masing-masing variabel independen menunjukkan nilai lebih besar dari 0.05. Dapat disimpulkan bahwa tidak terjadi heteroskedastisitas dalam penelitian ini.

\section{Analisis Regresi Linier Berganda}

Hasil analisis regresi linier berganda dari penelitian ini disajikan pada Tabel 7.

\section{Tabel 7}

Hasil Regresi Linier Berganda

\begin{tabular}{|c|c|c|c|}
\hline \multirow[b]{2}{*}{ Model } & \multicolumn{2}{|c|}{$\begin{array}{l}\text { Unstandardized } \\
\text { Coefficients }\end{array}$} & \multirow{2}{*}{$\begin{array}{c}\text { Standardized } \\
\text { Coefficients } \\
\text { Beta }\end{array}$} \\
\hline & B & $\begin{array}{l}\text { Std. } \\
\text { Error }\end{array}$ & \\
\hline 1 (Constant) & 0,431 & 0,101 & \\
\hline CR & $-0,022$ & 0,042 & $-0,057$ \\
\hline ROA & $-0,143$ & 0,480 & $-0,263$ \\
\hline OFFERING & 0,641 & 0,312 & 0,222 \\
\hline UNDERWRITER & $-0,135$ & 0,057 & $-0,264$ \\
\hline
\end{tabular}

Sumber: Data diolah oleh peneliti, Tahun 2021

Berdasarkan Tabel 7, berikut diperoleh persamaan analisis regresi linier berganda dalam penelitian, yaitu:

$$
\begin{aligned}
\text { NIR }= & 0.431-0.022 \text { CR }-0.143 \text { ROA }+0.641 \\
& \text { OFFERING } \quad- \\
& \text { UNDERWRITER }+\varepsilon
\end{aligned}
$$

Keterangan:

$\begin{array}{ll}\text { NIR } & : \text { Net Initial Return } \\ \text { CR } & : \text { Current Ratio } \\ \text { ROA } & : \text { Return on Asset } \\ \text { OFFERING } & : \text { Offering } \\ \text { UNDERWRITER } & : \text { Reputasi Underwriter } \\ \varepsilon & : \text { Error }\end{array}$

\section{Hasil Koefisien Determinasi $\left(\mathbf{R}^{\mathbf{2}}\right)$}

Hasil koefisien determinasi $\left(\mathrm{R}^{2}\right)$ dari penelitian ini disajikan pada Tabel 8 .

Tabel 8

Hasil Koefisien Determinasi $\left(\mathbf{R}^{2}\right)$

\begin{tabular}{lrrrr}
\hline Model & R & R Square & $\begin{array}{r}\text { Adjusted } \\
\text { R Square }\end{array}$ & $\begin{array}{l}\text { Std. Error of } \\
\text { the Estimate }\end{array}$ \\
\hline 1 & $0,561^{\mathrm{a}}$ & 0,315 & 0,298 & 2,4981 \\
\hline
\end{tabular}

Sumber: Data diolah oleh peneliti, Tahun 2021

Berdasarkan Tabel 8 di atas menunjukkan hasil pengujian koefisien determinasi yang memiliki tujuan untuk melihat seberapakah variabel independen mampu menjelaskan variabel dependen. Nilai Adjusted R-Square sebesar 0.298 atau $29.8 \%$ yang menunjukkan bahwa variabel independen yaitu Current Ratio (CR), Return On Asset (ROA), Offering, dan Reputasi Underwriter mampu menjelaskan variabel dependen yakni Net Initial Return sebesar $29.8 \%$ dan sebesar $70.2 \%$ dipengaruhi oleh faktor lainnya di luar variabel yang digunakan dalam penelitian ini.

\section{Hasil Pengujian Simultan (Uji F)}


Hasil uji F dari penelitian ini disajikan pada Tabel 9.

\section{Tabel 9}

Hasil Uji F

\begin{tabular}{lrrrrr}
\hline Model & $\begin{array}{c}\text { Sum of } \\
\text { Squares }\end{array}$ & Df & $\begin{array}{c}\text { Mean } \\
\text { Square }\end{array}$ & F & Sig. \\
\hline 1 Regression & 1,072 & 4 & 0,214 & 5,498 & $0,000^{\mathrm{b}}$ \\
$\quad$ Residual & 3,217 & 66 & 0,049 & & \\
$\quad$ Total & 4,289 & 70 & & & \\
\hline
\end{tabular}

Sumber: Data diolah oleh peneliti, Tahun 2021

Berdasarkan Tabel 9 menunjukkan nilai signifikansi sebesar 0.000 yang berarti $<\alpha=5 \%$ (0.05) maka $\mathrm{H}_{0}$ ditolak dan $\mathrm{H}_{1}$ diterima, hal ini menjelaskan bahwa Current Ratio (CR), Return on Asset (ROA), Offering, dan Reputasi Underwriter berpengaruh signifikan secara simultan terhadap Net Initial Return pada perusahaan yang melakukan Initial Public Offering (IPO) di Bursa Efek Indonesia pada periode 2015-2019.

\section{Pengujian Parsial (Uji t)}

Hasil uji $\mathrm{t}$ dari penelitian ini disajikan pada Tabel 10.

Tabel 10

Hasil Uji t

\begin{tabular}{|c|c|c|c|c|c|}
\hline \multirow[b]{2}{*}{ Model } & \multicolumn{2}{|c|}{$\begin{array}{l}\text { Unstandardize } \\
\text { d Coefficients }\end{array}$} & \multirow{2}{*}{$\begin{array}{c}\begin{array}{c}\text { Standardized } \\
\text { Coefficients }\end{array} \\
\text { Beta }\end{array}$} & \multirow{3}{*}{$\frac{\mathbf{t}}{4.280}$} & \multirow{3}{*}{$\frac{\text { Sig. }}{0,000}$} \\
\hline & B & $\begin{array}{c}\text { Std. } \\
\text { Error }\end{array}$ & & & \\
\hline $1 \quad$ (Constant) & 0,431 & 0,101 & & & \\
\hline $\mathrm{CR}$ & $-0,022$ & 0,042 & $-0,057$ & $-0,534$ & 0,595 \\
\hline ROA & $-0,143$ & 0,480 & $-0,263$ & $-2,384$ & 0,020 \\
\hline OFFERING & 0,641 & 0,312 & 0,222 & 1,987 & 0,074 \\
\hline UNDERWRITER & $-0,135$ & 0,057 & $-0,264$ & $-2,382$ & 0,020 \\
\hline
\end{tabular}

Sumber: Data diolah oleh peneliti, Tahun 2021

Berdasarkan Tabel 10 dapat dilihat bahwa koefisien regresi variabel Current Ratio (CR) adalah sebesar -0.022 dengan nilai signifikansi sebesar 0.595 di mana nilai tersebut lebih dari $(\alpha)$ sebesar 0.05 . Nilai tersebut menjelaskan bahwa variabel Current Ratio (CR) tidak berpengaruh signifikan terhadap Net Initial Return dengan hipotesis $\mathrm{H}_{0}$ diterima serta $\mathrm{H}_{\mathrm{a}}$ ditolak dan memiliki arah negatif terhadap Net Initial Return dapat dilihat pada nilai koefisien Current Ratio yaitu sebesar -0.022 .

Tidak berpengaruhnya Current Ratio terhadap Net Initial Return dapat disebabkan karena perbedaan penilaian investor terhadap nilai Current Ratio. Beberapa investor menilai bahwa perusahaan dengan Current Ratio tinggi dapat diartikan oleh investor sebagai ketidaktepatan dalam mengalokasikan dana perusahaan karena menunjukkan adanya dana yang tidak terkelola dengan efisien. Investor juga beranggapan bahwa penggunaan hutang jangka pendek dianggap belum bisa meminimalkan underpricing, karena umumnya perusahaan lebih memilih dan berfokus kepada penggunaan hutang jangka panjang sebab kondisi perusahaan pada saat IPO baru beroperasi secara luas pada saat hari pasar perdana, karena baru satu hari tentu likuiditas tidak dapat berkontribusi besar bagi peningkatan harga saham, sebagai elemen pendorong terbentuknya Net Initial Return (Rivandi, 2017).

Pada Tabel 10 juga menunjukkan bahwa koefisien regresi variabel Return On Asset (ROA) adalah sebesar -0.143 dengan nilai signifikansi sebesar 0.020 di mana nilai tersebut kurang dari $(\alpha)$ sebesar 0.05. Nilai tersebut menjelaskan bahwa variabel Return On Asset (ROA) berpengaruh signifikan terhadap Net 
Initial Return (NIR) dengan hipotesis $\mathrm{H}_{0}$ ditolak serta $\mathrm{H}_{\mathrm{a}}$ diterima dan memiliki arah negatif terhadap Net Initial Return. Nilai koefisien negatif menunjukkan hubungan berlawanan arah antara variabel Return On Asset (ROA) dengan Net Initial Return. Semakin tinggi Return On Asset (ROA) perusahaan akan mempengaruhi rendahnya tingkat Net Initial Return.

Dengan adanya pengaruh negatif, menjelaskan bahwa semakin tinggi Return On Asset (ROA) suatu perusahaan, perusahaan tersebut dianggap memiliki image yang baik serta mampu dalam menghasilkan laba yang tinggi dengan aset-aset perusahaan sehingga investor memiliki minat yang cukup tinggi dalam menanamkan modalnya karena Return On Asset (ROA) yang tinggi dapat mengurangi tingkat ketidakpastian (Kuncoro \& Suryaputri, 2019). Tertariknya investor, maka akan mengakibatkan harga penawaran saham perdana saat perusahaan melakukan IPO menjadi tinggi, sehingga akan menurunkan nilai Net Initial Return.

Dari Tabel 10 dapat juga dilihat bahwa koefisien regresi variabel Offering adalah sebesar 0.641 dengan nilai signifikansi sebesar 0.074 dimana nilai tersebut kurang dari $(\alpha)$ sebesar 0.05 . Nilai tersebut menjelaskan bahwa variabel Offering berpengaruh signifikan terhadap Net Initial Return (NIR) dengan hipotesis $\mathrm{H}_{0}$ diterima serta $\mathrm{H}_{\mathrm{a}}$ ditolak dan memiliki arah positif terhadap Net Initial Return. Nilai koefisien positif menunjukkan hubungan searah antara variabel Offering dengan Net Initial Return. Semakin tinggi tingkat Offering akan mempengaruhi tingginya tingkat Net Initial Return.
Tidak berpengaruhnya Offering terhadap Net Initial Return disebabkan besar kecilnya porsi saham yang ditawarkan ke publik belum mampu menjelaskan prospek dan kondisi perusahaan di masa yang akan datang. Walaupun porsi saham yang ditawarkan ke publik tinggi, tidak berarti privat informasi perusahaan tersebut tidak ada dan belum mampu menentukan nilai ketidakpastian return yang diberikan di masa mendatang (Pahlevi, 2014). Dapat disimpulkan bahwa besar atau kecil nya nilai Offering suatu perusahaan tidak memiliki pengaruh terhadap Net Initial Return.

Selain itu Tabel 10 juga menunjukkan bahwa koefisien regresi variabel Reputasi Underwriter adalah sebesar -0.135 dengan nilai signifikansi sebesar 0.020 di mana nilai tersebut kurang dari $(\alpha)$ sebesar 0.05 . Nilai tersebut menjelaskan bahwa variabel Reputasi Underwriter berpengaruh signifikan terhadap Net Initial Return (NIR) dengan hipotesis $\mathrm{H}_{0}$ ditolak serta $\mathrm{H}_{\mathrm{a}}$ diterima dan memiliki arah positif terhadap Net Initial Return. Nilai koefisien negatif menunjukkan hubungan berlawanan arah antara variabel Reputasi Underwriter dengan Net Initial Return. Semakin tinggi atau baik Reputasi Underwriter akan mempengaruhi rendahnya tingkat $\mathrm{Net}$ Initial Return.

Dengan adanya pengaruh negatif, semakin baik kualitas dan reputasi penjamin emisi efek suatu perusahaan dianggap dapat mengurangi ketidakpastian yang akan mengakibatkan penurunan terhadap Net Initial Return. Penjamin emisi efek yang memiliki reputasi baik akan sebaik mungkin dalam 
meminimalisir risiko yang akan terjadi pada saat penawaran umum saham perdana.

\section{KESIMPULAN DAN SARAN}

Berdasarkan hasil pengujian dan analisis yang telah dilakukan, dapat disimpulkan bahwa penelitian ini telah menjawab permasalahan dengan 1) Current Ratio tidak memiliki pengaruh signifikan terhadap Net Initial Return; 2) Return On Asset berpengaruh signifikan dengan arah negatif terhadap Net Initial Return; 3) Offering tidak memiliki pengaruh signifikan terhadap Net Initial Return; 4) Reputasi Undrewriter berpengaruh signifikan dengan arah negatif terhadap Net Initial Return. Hal tersebut membuktikan bahwa pentingnya variabel Return On Asset dan Reputasi Underwriter sebagai pertimbangan agar dapat untuk menghindari underpricing.

Dalam penelitian ini masih terdapat beberapa keterbatasan didalamnya seperti terdapat data outlier dan tidak lengkapnya prospektus perusahaan yang melakukan IPO di Bursa Efek Indonesia (BEI). Tentunya juga penelitian ini sangat jauh dari kata sempurna.

Peneliti selanjutnya disarankan untuk menggunakan variabel-variabel lainnya yang diindikasikan dapat mempengaruhi Net Initial Return seperti Financial Leverage dan Reputasi Auditor. Diharapkan dengan menambahkan variabel lain selain yang disebutkan dalam penelitian ini, peneliti selanjutnya dapat memunculkan pembaharuan dalam penelitiannya.

\section{DAFTAR PUSTAKA}

Albada, A., Yong, O., Hassan, M. E. M., \& Abdul-Rahim, R. (2018). Retention Ratio, Lock-Up Period And Prestige Signals And Their Relationship With Initial Public Offering (IPO) Initial Return: Malaysian Evidence. Asian Academy of Management Journal of Accounting and Finance, 14(2), 1-23.

Anah, S., Firdaus, I., \& Alliffah, E. (2018). Pengaruh Current Ratio, Debt To Equity Ratio Dan Price Book Value Terhadap Harga Saham Pada Sub Sektor Transportasi Yang Terdaftar Di Bei Periode 2012-2016. Jurnal Ekonomi, 23 (3), 403-416. https://doi.org/10.24912/ je.v23i3.421

Aryapranata, E. K., \& Adityamarwan. (2017). Pengaruh Reputasi Auditor, Reputasi Underwriter, Dan Persentase Free Float Terhadap Tingkat Underpricing Pada Initial Public Offering. Diponegoro Journal of Accounting, 6(2), 1-9.

Badru, B. O., \& Ahmad-Zaluki, N. A. (2018). Asian Review of Accounting Article information: Explaining IPO initial returns in Malaysia: ex-ante uncertainty versus signalling. Asian Review of Accounting, 26(1), 84-106. https:// doi.org/https://doi.org/10.1108/ARA-112016-0133

Fahmi, I. (2017). Pengantar Pasar Modal. Bandung: Alfabeta.

Gani, I., \& Amalia, S. (2018). Alat Analisis Data: Aplikasi Statistik untuk Penelitian Bidang Ekonomi dan Sosial (2nd ed.). Yogyakarta: CV ANDI Offset.

Ghozali, I. (2018). Aplikasi Analisis Multivariate Dengan Program IBM SPSS 25 (9th ed.). Badan Semarang: Penerbit Universitas Diponegoro.

Gunawan, M., \& Jodin, V. (2017). FaktorFaktor yang Mempengaruhi Tingkat Underpricing Saham Pada Perusahaan 
Ekonomi, 20(2), 174-192. https:// doi.org/10.24912/je.v20i2.155

Hadi, S. (2019). Faktor-Faktor yang Mempengaruhi Underpricing Saham Perdana Pada Perusahaan yang Melakukan Initial Public Offering. In Jurnal Akuntansi \& Perpajakan Jayakarta: Vol. I (Issue 1). http://journal.stiejayakarta.ac.id/index.php/ JAPJayakarta/article/view/8

Hidayati, D. N., \& Triyanto, D. N. (2020). Accounting Factors, Non-Accounting Factors, and Net Initial Return. Journal of Accounting Auditing and Business, 3(1), 29 -39 . jaab.v3i1.25019

Kartika, G. A. S., \& Putra, I. M. P. D. (2017). Faktor-Faktor Underpricing Initial Public Offering Di Bursa Efek Indonesia. Jurnal Akuntansi Universitas Udayana, 19(3), 2205-2233.

Khin, E. W. S., Wahh, W. B., \& Mohammad, N. (2016). An Analysis of Initial Public Offering (IPO) Underpricing on Smes Firms Performances. International Journal of Research Science \& Management, 3(6).

Kuncoro, H. B., \& Suryaputri, R. V. (2019). Analisis Faktor-Faktor Yang Mempengaruhi Underpricing Saham Pada Penawaran Umum Perdana. Jurnal Akuntansi Trisakti, 6(2), 213-234. https:// doi.org/http://dx.doi.org/10.25105/ jat.v6i2.5573

Linazah, Lailul, N., \& Setyowati. (2015). FaktorFaktor yang Mempengaruhi Underpricing Pada Perusahaan yang Melakukan Penawaran Umum Perdana. Jurnal Manajemen, 1(1), 1-9.

Maulidya, P. S., \& Lautania, M. F. (2016). Pengaruh Asset Turn Over, Current Ratio, Debt To Equity Ratio, dan Ukuran Perusahaan Terhadap Terjadinya Underpricing Saham. Jurnal Ilmiah Mahasiswa Ekonomi Akuntansi, 1(1), 171182. http://www.jim.unsyiah.ac.id/EKA/ article/view/764

Muklis, F. (2016). Perkembangan dan Tantangan
Pasar Modal Indonesia. In Al-Masraf: Jurnal Lembaga Keuangan dan Perbankan (Vol. 1, Issue 1). https:// doi.org/10.15548/AL-MASRAF.V1I1.25

Novitasari, D., \& Cahyati, A. D. (2018). FaktorFaktor yang Mempengaruhi Underpricing Saham pada Penawaran Umum Perdana di Bursa Efek Indonesia (Studi pada Perusahaan Non Keuangan yang Terdaftar di Bursa Efek Indonesia Tahun 20132016). Jurnal Penelitian Teori \& Terapan Akuntansi (PETA), 3(1), 34-64. http:// journal.stieken.ac.id/index.php/peta/ article/view/333

Pahlevi, R. W. (2014). Analisis Faktor-Faktor yang Mempengaruhi Underpricing Saham pada Penawaran Saham Perdana di Bursa Efek Indonesia. In Jurnal Siasat Bisnis (Vol. 18, Issue 2). https://journal.uii.ac.id/ JSB/article/view/3821

Purwanto. (2012). Pengaruh Manajemen Laba, Asymetry Information dan Pengungkapan Sukarela Terhadap Biaya Modal. Simposium Nasional Akuntansi XV.

Radipria, R., Yusniar, M. W., \& Juniar, A. (2015). Pengaruh Faktor Keuangan dan Non Keuangan Terhadap Nilai Underpricing pada Perusahaan yang Melakukan Initial Public Offering. In JWM (Jurnal Wawasan Manajemen) (Vol. 3, Issue 2). https://doi.org/10.20527/ JWM.V3I2.55

Rivandi, M. (2017). 307) Faktor Fundamental Sebagai Penentu Initial Return. Jurnal Benefita, 2(3), $299 . \quad$ https:// doi.org/10.22216/jbe.v2i3.2346

Rochaety, E., Tresnawati, R., \& Majid, A. (2019). Metodologi Penelitian Bisnis: Dengan Aplikasi SPSS (2nd ed.). Jakarta: Mitra Wacana Media.

Sanjaya, D., \& Lukman, H. (2020). Pengaruh Pengungkapan Faktor Risiko Dalam Prospektus Terhadap Initial Return Initial Public Offering. In Jurnal Paradigma Akuntansi (Vol. 2, Issue 1). https:// doi.org/10.24912/JPA.V2I1.7134 
Sari, M. N. (2020). Pengaruh Return on Asset, Financial Leverage dan Trading Volume Terhadap Initial Return. Jurnal Akuntansi Bisnis Dan Publik, 11(1), 18-27.

Scott, W. (2015). Financial Accounting Theory. Toronto: Pearson Canada Inc.

Setiawan, D. (2018). Determinan Underpricing Pada Saat Penawaran Saham Perdana. Assets: Jurnal Akuntansi Dan Pendidikan, 7(2), 111-119. https://doi.org/10.25273/ jap.v7i2.2474

Sugiyono. (2017). Metodologi Penelitian Bisnis. Yogyakarta: CV Alfabeta.

Sujarweni, V. W. (2015). Metodologi Penelitian Bisnis \& Ekonomi. Yogyakarta: Pustaka Baru Press.

Syukur, M., Fathoni, A., \& Gagah, E. (2018). The Influence Of Financial and Non Financial Information On Return Initial In Companies That Conduct IPO In Indonesia Stock Exchange. Journal of Management, 4 (4), 1-16.

Tambunan, A. P. (2015). Analisis Saham Perdana (IPO). Jakarta: PT Elex Media Komputindo.

Umam, K., \& Sutanto, H. (2017). Manajemen Investasi. Bandung: CV Pustaka Setia.

Wildahayu, M., \& Priantinah, D. (2019). Analisis Faktor-Faktor yang Mempengaruhi Initial Return. Kajian Pendidikan Akuntansi Indonesia, 8(4), 1-15. 